\title{
Fertilitas Semen Beku dalam Tris Kuning Telur dan Skim yang Diberi Omega-3 pada Sapi Simmental dengan Ransum Berimbuhan Seng dan Selenium Minimal
}

\author{
(FERTILITY OF FROZEN SEMEN IN TRIS YELLOW EGGS \\ AND SKIM ENTENDER WITH OMEGA-3 ON SIMMENTAL CATTLE \\ SUPPLEMENTED WITH ZINC AND SELENIUM)
}

\author{
Asep Kurnia ${ }^{1,2}$, Soeparna ${ }^{3}$, Raden Iis Arifiantini ${ }^{4}$, Rahmat Hidayat ${ }^{5}$ \\ ${ }^{1}$ Mahasiswa Program Doktor, Bidang ilmu Peternakan, \\ Fakultas Peternakan, Universitas Padjadjaran, \\ ${ }^{2}$ Balai Inseminasi Buatan, Lembang, Bandung \\ ${ }^{2}$ Laboratorium Reproduksi Ternak dan Inseminasi Buatan, Fapet Unpad \\ , ${ }^{3}$ Divisi Reproduksi dan Kebidanan, Departemen Klinik, Reproduksi dan Kebidanan, \\ Fakultas Kedokteran Hewan, Institut Pertanian Bogor \\ ${ }^{4}$ Laboratorium Nutrisi Ternak Ruminansia dan Kimia Makanan Ternak, Fapet Unpad \\ Jln. Raya bandung Sumedang, Jatinangor, Sumedang, Jawa Barat, Indoneia \\ Email: iis.arifiantinipurna@gmail.com; asep kurnia99@yahoo.com
}

\begin{abstract}
ABSTRAK
Penelitian ini bertujuan untuk menguji kualitas semen beku sapi simmental yang diberi tiga jenis komposisi pakan dalam pengencer Tris kuning telur dan skim yang diberi Omega-3. Sebanyak 18 ekor sapi pejantan simmental milik Balai Inseminasi Buatan (BIB) Lembang, dibagi menjadi tiga kelompok. Masing-masing diberi pakan standar (R1), pakan standar yang disuplementasi Se dan Zn minimal (R2) dan pakan standar yang disuplementasi Se dan Zn maksimal. Semen dikoleksi menggunakan vagina buatan dan dievaluasi secara makroskopis dan mikroskopis. Semen dibagi empat dan masing-masing diencerkan dengan Skim, Skim-Omega 3, TKT dan TKT-O. Semen kemudian dikemas ke dalam straw dan diekuilibrasi selama empat jam, kemudian dibekukan di atas uap nitrogen cair, dan disimpan dalam kontainer nitrogen cair $\left(-196^{\circ} \mathrm{C}\right)$. Kualitas semen beku diuji terhadapp motilitas, skor individu, viabilitas dan keutuhan membran plasma (MPU) spermatozoa. Hasil penelitian menunjukkan motilitas spermatozoa sapi yang diberi Ransum 1 dalam pengencer Tris Kuning telur dan Ransum 3 dalam pengencer Tris kuning telur dan TKT-Omega-3 paling tinggi $(\mathrm{p}<0,05)$ dibandingkan kombinasi lainnya. Skor gerak individu spermatozoa sapi pada semua ransum dan semua pengencer sama. Viabilitas spermatozoa pada sapi yang diberi Ransum standar dalam pengencer Skim-omega-3 paling tinggi dan keutuhan membran plasma spermatozoa tertinggi pada sapi yang diberi pakan R2 dalam pengencer Tris kuning telur.
\end{abstract}

Kata-kata kunci: pakan; simmental; tris kuning telur; skim dan omega-3

\begin{abstract}
-ABSTRACT
This study aims to examine the quality of frozen semen in Tris egg yolk (TEY) extender and skimmed milk extender with or witout omega-3. A total of 18 Simmental bulls belong to Lembang Artificial Insemination Centre were divided into three groups. Each was fed with standard feed (R1), standard feeds supplemented with minimal Se and Zn (R2) and standard feed supplemented with maximal of Se and Zn concentration. Semen were collected using an artificial vagina and were evaluated macro- and microscopically. The semen then were divided into four tubes and each diluted with Skimmed, SkimmedOmega 3, TEY or TEY-O. The semen was then packed into a $0.25 \mathrm{ml}$ straw and equilibrated at $5{ }^{\circ} \mathrm{C}$ for 4 hours, then frozen above liquid nitrogen vapor, and stored in liquid nitrogen container $\left(-196{ }^{\circ} \mathrm{C}\right)$. The qualities of frozen semen were evaluated on the motility, individual score, viability and integrity of the plasma membrane of sperms. Sperm motility of bulls fed with standard feed (R1) in TEY extender and R3 in TEY and TEY-Omega-3 extender were higher $(\mathrm{p}<0.05)$ compared to the other combinations. No difference
\end{abstract}


was found on the individual score. The viability of sperms in bulls fed with standard feed in SkimmedOmega-3 extender was higher than the other treatments and the highest sperm plasma membrane integrity was demonstrated by sperm in bull feeding with R2 in TEY extender.

Keywords: feeding; bull semen; tris egg-yolk; skimmed; omega-3

\section{PENDAHULUAN}

Kementerian Pertanian mengeluarkan program Upaya Khusus Percepatan Populasi Sapi dan Kerbau Bunting (Upsus Siwab) pada bulan Oktober 2016. Program ini untuk menunjang percepatan target pemenuhan populasi sapi potong dalam negeri dalam upaya mengejar tercapainya target swasembada sapi tahun 2026. Upsus Siwab mencakup dua program utama yaitu peningkatan populasi melalui Inseminasi Buatan (IB) dan intensifikasi kawin alam (Inka).

Balai Inseminasi Buatan (BIB) merupakan Unit Pelaksana Teknis (UPT) di bawah Direktorat Jenderal Peternakan dan Kesehatan Hewan yang bertugas menghasilkan semen beku untuk digunakan dalam IB. Kualitas semen beku dapat dipengaruhi oleh beberapa faktor di antaranya kualitas semen segar, jenis dan konsentrasi krioprotektan, metode pembekuan, jenis pengencer yang digunakan, dan laju penurunan suhu (Herdiawan, 2004; Setiono et al., 2015).

Kualitas semen segar dipengaruhi oleh genetik pejantan, teknik koleksi, dan pakan yang diberikan. Pakan, terutama konsentrat sangat penting untuk pejantan dalam menghasilkan spermatozoa (Walker et al., 2009). Penelitian yang dilakukan Cheah dan Yang, (2011) menunjukkan pengaruh pakan terhadap spermatogenesis dan kualitas semen yang diejakulasikan. Beberapa mineral mikro telah diteliti dapat memperbaiki kualitas semen. Kumar et al. (2006) menyatakan pemberian Zn anorganik maupun $\mathrm{Zn}$ organik dapat meningkatkan kualitas dan kuantitas semen sapi. Seng (Zn) menurut Cheah dan Yang (2011) berperan dalam sistem reproduksi jantan, di antaranya berperan dalam aktifitas enzim ribonuclease yang sangat tinggi dalam proses mitosis spermatogonia dan meiosis dari spermatosis.

Selenium (Se) berperan sebagai antioksidan yang mampu mencegah kerusakan kromosom dan menjaga kesuburan. Selenium merupakan key element dalam spermatogenesis dan fertilitas jantan (Boitani dan Puglisi, 2008). Selenium dapat meningkatkan jumlah spermatid, terutama bekerja dalam mengubah spermatosit dalam pembelahan meiosis kedua untuk membentuk spermatid (Ganabadi et al., 2010).

Sapi simmental merupakan salah satu sapi eksotik yang banyak diminati oleh peternak. Sapi ini terkenal sebagai sapi dwiguna sebagai penghasil susu dan daging yang baik. Pengembangbiakan sapi simmental saat ini sebagian besar dengan IB menggunakan semen beku. Semen beku adalah semen yang telah diberikan bahan pengencer yang mengandung krioprotektan, dibekukan dan disimpan dalam nitrogen cair suhu $-196^{\circ} \mathrm{C}$. Saat pembekuan spermatozoa akan mengalami kerusakan terutama pada bagian membran plasma. Kerusakan membran spermatozoa menurut Nalley dan Arifiantini (2011) dapat dikurangi dengan penambahan omega-3 dalam bahan pengencer. Omega-3 adalah lemak-lemak yang umumnya dijumpai dalam minyak ikan dan minyak nabati serta merupakan asam lemak poli tak jenuh. Omega-3 memiliki kandungan asam lemak tak jenuh atau Polyunsaturated Fatty Acid (PUFA) serta Eicosa Pentaenoic Acid (EPA) dan Docosahexaenoic Acid (DHA) sebagai pelindung membran plasma.

Towhidi et al. (2013) menyatakan pemberian PUFA dan á- tokoferol secara in vitro dapat melindungi spermatozoa domba saat proses kriopreservasi. Penelitian ini bertujuan untuk menguji pengaruh pakan dan pemberian Omega-3 dalam pengencer Tris kuning telur dan skim terhadap fertilitas semen beku sapi pejantan Simmental

\section{METODE PENELITIAN}

Penelitian ini dilaksanakan pada bulan Agustus sampai Oktober tahun 2016 di Balai Inseminasi Buatan Lembang dan di Unit Rehabilitasi Reproduksi, Divisi Reproduksi dan Kebidanan, Departemen Klinik, Reproduksi dan Patologi, Fakultas Kedokteran Hewan, Institut Pertanian Bogor.

\section{Peajantan Sapi Simental}

Sebanyak 18 ekor pejantan Simmental dibagi menjadi tiga perlakuan masing-masing 
enam ekor. Kelompok I diberi pakan standar (R1), kelompok II diberi pakan yang diberi suplementasi Se, Zn minimalis dan kelompok III diberi pakan yang suplementasi Se dan Zn maksimal (Tabel 1).

\section{Penyiapan Bahan Pengencer}

Bahan pengencer yang disiapkan adalah empat pengencer, yaitu Skim, Skim Omega-3 (Skim-O), Tris Kuning Telur (TKT) dan Tris Kuning Telur dengan omega-3 (TKTO). Bahan pengencer skim dibuat dengan cara melarutkan $10 \mathrm{~g}$ susu skim (Tropicana Slim) dalam $100 \mathrm{~mL}$ aquadest. Larutan susu dipanaskan sampai suhu $90-92^{\circ} \mathrm{C}$ selama 10 menit. Setelah dingin disaring dan ditambahkan antibiotik (Penicillin 100.000 IU dan Streptomysin $100 \mathrm{mg}$ dalam larutan $10 \mathrm{~mL}$ aquadest). Perbandingan antibiotik dan larutan skim adalah $1: 100$. Pengencer untuk semen beku adalah $86 \mathrm{~mL}$ susu skim yang telah diberi antibiotik dengan $5 \mathrm{~mL}$ kuning telur, dan $8 \mathrm{~mL}$ gliserol ditambah $1 \mathrm{~g}$ glukosa. Pengencer selanjutnya dibagi dua, satu bagian merupakan pengencer kontrol dan satu bagian ditambah omega-3.
Bahan pengencer TKT disiapkan dengan cara mencampurkan 3,028 g Tris-hydroxymethyl-aminomethane dengan $1,78 \mathrm{~g}$ monohydrate citric acid dan 1,25 D-fructose, dan dilarutkan dalam $100 \mathrm{~mL}$ aquadest (Arifiantini dan Yusuf, 2010). Larutan Tris $80 \mathrm{~mL}$ ditambah $20 \mathrm{~mL}$ kuning telur disentrifus $3000 \mathrm{rpm}$ selama 15 menit, diambil supernatan sebanyak $94 \mathrm{~mL}$, kemudian ditambahkan dengan $6 \mathrm{~mL}$ gliserol. Larutan pengencer ditambah dengan antibiotik sama dengan yang diberikan pada pengencer skim. Pengencer selanjutnya dibagi dua, satu bagian merupakan pengencer kontrol dan satu bagian ditambah dengan Omega-3, sehingga ada empat kombinasi bahan pengencer (Tabel 2).

\section{Koleksi dan evaluasi semen}

Semen dikoleksi menggunakan vagina buatan dua kali dalam seminggu, sesuai POB BIB Lembang, pada pagi hari antara jam 07.0010.00. Semen yang telah dikoleksi dievaluasi secara makroskopis dan mikroskopis.

Evaluasi makroskopis meliputi, volume semen dinilai secara visual pada skala yang

Tabel 1. Komposisi pakan perlakuan

\begin{tabular}{lccccc}
\hline Bahan & Umur & BB/Kg & R1 Standar & R2 & R3 \\
\hline BK & 7 & 1000 & 13,96 & 13,96 & 13,96 \\
TDN & 7 & 1000 & 7,3 & 8,2 & 7,3 \\
PK & 7 & 1000 & 1,227 & 2,63 & 1,227 \\
Ca & 7 & 1000 & 0,041 & 0,133 & 0,041 \\
F & 7 & 1000 & 0,025 & 0,066 & 0,025 \\
Mn & 7 & 1000 & 0,00035 & 0.00035 & 0,00035 \\
Zn & 7 & 1000 & 0 & 0,002 & 0,001 \\
Se & 7 & 1000 & 0 & 0,003 & 0,007 \\
\hline
\end{tabular}

Keterangan: (BK,TDN,PK,Ca,F) NRC. $\mathrm{Mn}=0,20-0,60 \mathrm{mg} / \mathrm{kg} \quad \mathrm{Zn}=10-50 \mathrm{mg} / \mathrm{kg} \quad \mathrm{Se}=0,05-0,3 \mathrm{ppm}, \mathrm{tkg}$ $=$ total pakan dalam kilogram

Pemberian pakan dilakukan selama 52 hari (satu siklus spermatogenesis)

Tabel 2. Kombinasi perlakuan bahan pengencer

\begin{tabular}{lcccc}
\hline \multirow{2}{*}{ Bahan } & \multicolumn{4}{c}{ Pengencer } \\
\cline { 2 - 5 } & Skim & Skim-O & TKT & TKTO \\
\hline Skim & $\sqrt{ }$ & $\sqrt{ }$ & $\sqrt{ }$ & $\sqrt{ }$ \\
TKT & & $\sqrt{ }$ & & $\sqrt{ }$ \\
Omega 3 & & & & \\
\hline
\end{tabular}


dapat dibaca pada tabung penampungan. Derajat keasaman $(\mathrm{pH})$ semen diukur menggunakan kertas $\mathrm{pH}$ indikator. Kertas $\mathrm{pH}$ dicelupkan pada semen. Warna yang muncul disesuaikan dengan indikator. Warna semen dilihat secara visual dan konsistensi semen dinilai dengan cara memiringkan tabung dan mengembalikan pada posisi semula. Nilai konsistensi adalah encer, sedang atau kental.

Evaluasi mikroskopis meliputi gerakan massa spermatozoa yaitu gelombang atau pergerakan sperma secara bersama-sama. Penilaiannya adalah $+++=$ gelombang besarbesar, jumlahnya banyak dan cepat berpindahpindah tempat. $++=$ gelombang kecil-kecil jumlahnya sedikit dan lambat berpindah. $+=$ gelombang-gelombang tidak ada, hanya terlihat gerakan sperma sendiri-sendiri. $\mathrm{N}=$ tidak ada sperma yang bergerak, semua mati.

Pemeriksaan motilitas sperma menggunakan mikroskop yang dilengkapi dengan monitor. Satu tetes semen ditambahkan 3 sampai 4 tetes $\mathrm{NaCl}$ dihomogenkan dan dipindahkan satu tetes pada gelas obyek lain dan ditutup dengan gelas penutup. Preparat dilihat di bawah mikroskop pembesaran $200 \mathrm{x}$ atau 400 x. Jumlah sperma yang progresif maju ke depan dibandingkan dengan gerakan-gerakan lain. Nilai dinyatakan dalam persen. Konsentrasi sperma dapat dihitung dengan menggunakan photometer SDM 5. Semen diencerkan dengan $\mathrm{NaCl}$ fisiologis 100 kali dan dimasukan ke dalam cuvet. Nilai konsentrasi dapat dilihat langsung dalam display.

\section{Pengolahan Semen}

Semen sapi dari masing-masing perlakuan pakan (R1, R2 dan R3) dibagi empat. Masingmasing semen diencerkan dengan pengencer semen standar dan pengencer yang mengandung omega 3 . Dosis pengenceran adalah 100 juta per $\mathrm{mL}$ ( $25 \mathrm{juta} / \mathrm{straw}$ ). Semen selanjutnya dikemas menggunakan mini straw, diequilibrasi dan dibekukan. Semen yang telah dibekukan disimpan dalam kontainer nitrogen cair sampai pengujian lebih lanjut.

\section{Pengujian semen beku}

Semen yang telah dibekukan di thawing menggunakan air hangat $37^{\circ} \mathrm{C}$ selama 30 detik. Kedua sumbat lab dan pabrik digunting, dan semen dimasukkan dalam mikrotub. Kualitas semen yang diuji adalah motilitas sperma, kecepatan sperma dan keutuhan membran plasma.

\section{Peubah yang diukur}

\section{a. Post Thawing Motility (PTM).}

Penilaian motilitas setelah thawing dilakukan dengan cara meneteskan satu tetes semen pada gelas objek dan ditutup dengan gelas penutup kemudian diperiksa menggunakan mikroskop cahaya dengan perbesaran 400 kali dan dinilai persentase motilitasnya.

b. Keutuhan Membran Plasma (MPU).

Keutuhan membran plasma dilakukan menggunakan teknik osmotic resistance test (ORT) atau hypoosmotic swelling (HOS) test (Fonseca et al., 2005). Sebanyak 50 iL semen dimasukkan dalam 1000 iL larutan HOS $(1,351 \mathrm{~g}$ fruktosa dan 0,735 g Na-sitrat dalam $100 \mathrm{~mL}$ aquadest dengan osmolaritas $150 \mathrm{~m}$ osmol). Campuran dihomogenkan kemudian diinkubasi pada suhu $37^{\circ} \mathrm{C}$ selama 30 menit.

Satu tetes larutan yang telah diinkubasi diteteskan di atas gelas objek kemudian ditutup dengan gelas penutup.

Tabel 3 Kombinasi perlakuan pakan dan bahan pengencer

\begin{tabular}{lllll} 
Ransum & \multicolumn{3}{c}{ Pengencer } \\
& Skim & Skim-O & TKT & TKTO \\
\hline R1 & R1-Skim & R1-Skim-O & R1-TKT & R1-TKTO \\
R2 & R2-Skim & R2-Skim-O & R2-TKT & R2-TKTO \\
R3 & R3-Skim & R3-Skim-O & R3-TKT & R3-TKTO \\
\hline
\end{tabular}

Pengencer

R1 : Pakan standar

R2 : Pakan dengan supplementasi Zn dan Se minimal

R2 : Pakan dengan supplementasi Zn dan Se maksimal

TKT $=$ Tris kuning Telur

$\mathrm{O}=$ Omega 3 
Evaluasi dilakukan secara acak pada 10 lapangan pandang dalam mengamati minimal 200 spermatozoa. Penghitungan dilakukan menggunakan mikroskop phase kontras pembesaran 400 kali. Spermatozoa yang memiliki membran plasma utuh ditandai oleh ekor melingkar atau menggembung, sedangkan yang rusak ditandai oleh ekor yang lurus.

c. Rasio Spermatozoa Hidup dan Mati (Viabilitas).

Satu tetes semen dengan dua tetes pewarna eosin dihomogenkan, dibuat preparat ulas pada gelas objek dan difiksasi di atas heating table. Perhitungan dilakukan pada 10 lapang pandang dengan jumlah spermatozoa yang diamati minimal 200 sel (Arifiantini, 2012), menggunakan mikroskop cahaya (Olympus BX 51) dengan pembesaran 400 kali. Spermatozoa yang mati bersifat menyerap warna sedangkan yang hidup tidak menyerap warna (transparan).

d. Kecepatan Laju Spermatozoa (speed/ velocity).

Kecepatan spermatozoa bergerak mengadopsi dari Australian Association of Cattle Veterinarians (AACV) Scoring System

\section{Analisis Data}

Penelitian ini menggunakan rancangan acak lengkap, pola faktorial $3 \times 4$, yakni tiga perlakuan pakan dan empat perlakukan pengencer. Rumpun dan umur sapi seragam, serta manajemen pemeliharaan yang sama. Pakan menjadi faktor perlakukan pertama yaitu pakan standar (R1), pakan dengan suplementasi mineral minimal (R2) dan pakan dengan mineral maksimal (R3). Faktor kedua adalah

Tabel 4. Kriteria Skor Individu gerakan spermatozoa

\begin{tabular}{ll}
\hline Skor & Kriteria \\
\hline 0 & Tidak ada pergerakan \\
1 & Gerakan maju yang sangat lambat \\
2 & Gerakan maju yang lambat \\
3 & Gerakan maju yang sedang (moderate) \\
4 & Gerakan maju yang cepat \\
5 & Gerakan maju yang sangat cepat \\
\hline Sumber: & Australian Association of Cattle \\
& Veterinarians (AACV) Scoring System
\end{tabular}

pengencer semen. Semen diencerkan dengan menggunakan empat macam pengencer yaitu Skim, Skim omega-3, TKT dan TKT omega-3. Ulangan sapi masing-masing tiga ekor dengan masing-masing lima straw pengencer. Data yang diperoleh dari pengamatan post thawing dianalisis dengan sidik ragam pada taraf $5 \%$, dan perbedaan antar perlakuan dilanjutkan dengan uji Duncan.

\section{HASIL DAN PEMBAHASAN}

\section{Kualitas Semen Segar Sapi Simmental}

Kualitas semen segar untuk pembekuan semen yang berasal dari sapi simmental yang diberi tiga jenis ransum berbeda disajikan pada Tabel 5. Pada Tabel 5 ditunjukkan volume semen sapi antara 5,0 $\pm 1,04$ sampai 7,33 $\pm 2,08$ $\mathrm{mL}$, berwarna krem dengan $\mathrm{pH}$ 6,4 dan konsistensi sedang sampai kental. Secara mikroskopis menunjukkan nilai gerakan massa yang sama yaitu $2,33 \pm 0,57$. Motilitas spermatozoa menunjukkan nilai yang sedang yaitu berkisar antara $66,66 \%$ sampai dengan 73,33\%.

Konsentrasi spermatozoa cukup baik yaitu $1336,33 \pm 196$ sampai dengan $1373,66 \pm 218 \times 10^{6}$ per mL. Viabilitas spermatozoa cukup tinggi yaitu $73,54 \pm 4,86$ sampai $79,42 \pm 6,3 \%$ dengan nilai membran plasma utuh antara $56,35 \pm 4,69$ sampai dengan $70,87 \pm 6,62 \%$. Kualitas semen segar sapi simmental ini cukup baik, dalam kisaran semen sapi menurut Ax et al. (2000), dan dapat diproses lebih lanjut menjadi semen beku.

\section{Pengaruh pakan dan pengencer terhadap kualitas semen beku \\ Proses pembekuan dapat menyebabkan} kerusakan sel spermatozoa. Setiap tahapan harus dievaluasi agar dapat diketahui titik kritis proses pembekuan. Kerusakan spermatozoa pertama terlihat setelah 4 jam ekuilibrasi. Pengujian kualitas setelah ekuilibrasi hanya dilakukan pada motilitas spermatozoa. Penelitian ini menunjukkan tidak terlihat interaksi antara pakan yang diberikan dengan pengencer yang digunakan. Motilitas spermatozoa setelah ekuilibrasi pada berbagai bahan pengencer disajikan pada Tabel 6 .

Motilitas spermatozoa setelah ekuilibrasi tidak berbeda $(p>0,5)$ antar pengencer dan ransum yang digunakan. Pada sapi-sapi yang diberi R1 motilitas spermatozoa berkisar antara 
Tabel5. Kualitas semen segar sapi simmental yang digunakan untuk pembekuan semen menggunakan berbagai bahan pengencer

\begin{tabular}{|c|c|c|c|}
\hline \multirow{2}{*}{ Parameter } & \multicolumn{3}{|c|}{ Ransum } \\
\hline & $\mathrm{R} 1$ & $\mathrm{R} 2$ & R3 \\
\hline \multicolumn{4}{|l|}{ Makroskopis } \\
\hline Volume semen (mL) & $7,33 \pm 2,08$ & $5,0 \pm 1,04$ & $6,16 \pm 2,81$ \\
\hline Warna & Krem & Krem & Krem \\
\hline $\mathrm{pH} 6,4 \pm 0,0$ & $6,4 \pm 0,0$ & $6,4 \pm 0,0$ & \\
\hline Konsistensi & $2,5 \pm 0,57$ & $2,5 \pm 0,57$ & $2,5 \pm 0,57$ \\
\hline \multicolumn{4}{|l|}{ Mikroskopis } \\
\hline Gerakan Massa & $2,33 \pm 0,57$ & $2,33 \pm 0,57$ & $2,33 \pm 0,57$ \\
\hline Motilitas spermatozoa (\%) & $73,33 \pm 2,88$ & $66,66 \pm 2,88$ & $70,00 \pm 0,0$ \\
\hline Konsentrasi spermatozoa (x106/mL) & $1336,33 \pm 196$ & $1373,66 \pm 218$ & $1355 \pm 29,28$ \\
\hline Viabilitas spermatozoa (\%) & $79,42 \pm 6,3$ & $73,54 \pm 4,86$ & $76,47 \pm 9,38$ \\
\hline MPU spermatozoa (\%) & $61,83 \pm 3,93$ & $70,87 \pm 6,62$ & $56,35 \pm 4,69$ \\
\hline
\end{tabular}

Keterangan: R1 = Pakan standar; R2= Pakan dengan supplementasi Zn dan Se minimal; R3 = Pakan dengan supplementasi Zn dan Se maksimal; Konsistensi: encer (1), sedang (2), kental (3); Gerakan massa spermatozoa: $+(1),++(2)$ dan $+++(3)$

Tabel 6. Motilitas spermatozoa semen sapi simmental setelah ekuilibrasi dalam berbagai bahan pengencer

\begin{tabular}{lcccc}
\hline & \multicolumn{3}{c}{ Pengencer } \\
\cline { 2 - 5 } Pakan & Skim & Skim-O & TKT & TKT-O \\
\hline R1 & $61,67 \pm 15,28 \mathrm{a}$ & $55,00 \pm 18,03 \mathrm{a}$ & $60,00 \pm 18,03 \mathrm{a}$ & $60,00 \pm 15,00 \mathrm{a}$ \\
R2 & $63,33 \pm 7,64 \mathrm{a}$ & $61,67 \pm 12,58 \mathrm{a}$ & $61,67 \pm 18,93 \mathrm{a}$ & $60,00 \pm 15,00 \mathrm{a}$ \\
R3 & $63,33 \pm 7,64 \mathrm{a}$ & $60,00 \pm 5,00 \mathrm{a}$ & $66,67 \pm 2,89 \mathrm{a}$ & $66,67 \pm 2,89 \mathrm{a}$ \\
\hline
\end{tabular}

Keterangan: R1=Pakan standar; R2= Pakan dengan supplementasi Zn dan Se minimal; R3= Pakan dengan supplementasi Zn dan Se maksimal; Huruf yang mengikuti angka pada baris dan kolom yang sama menunjukkan tidak ada perbedaan nyata $(\mathrm{p}<0.05)$

$55,00 \pm 18,03$ sampai $61,67 \pm 15,28 \%$. Sapi yang diberi R2, motilitasnya $60,00 \pm 15,00$ sampai $63,33 \pm 7,64$ dan sapi yang diberi R3 60,00 $\pm 5,00$ sampai $66,67 \%$. Tidak berbedanya motilitas spermatozoa pada sapi-sapi yang diberi ransum R1, R2 dan R3 serta empat bahan pengencer berbeda dapat diartikan sampai dengan tahap ekuilibrasi ransum yang digunakan serta jenis pengencer mempunyai kemampuan yang sama dalam melindungi sel saat ekuilibrasi. Ekuilibrasi dilakukan pada suhu $5^{\circ} \mathrm{C}$ selama 4 jam, pada suhu ini nampaknya pakan tidak berpengaruh. Kandungan fosfolipid dalam susu dan kuning telur dalam TKT, sudah dapat melindungi membran plasma dari cold shock.

Tolok ukur keberhasilan pembekuan semen adalah jumlah spermatozoa yang progresif setelah thawing. Motilitas spermatozoa setelah thawing pada sapi simmental yang telah diberi tiga komposisi ransum dan empat bahan pengencer semen disajikan pada Tabel 7 . Motilitas terendah $(\mathrm{p}<0.05)$ ditunjukkan oleh spermatozoa yang diberi ransum R1 dalam pengencer Skim.

Motilitas tertinggi $(p<0,05)$ ditunjukkan oleh sperma dalam pengencer TKTO $(49,72 \pm 0,52 \%)$ yang diberi R2 dan TKT $(45,42 \pm 2,81 \%)$ serta TKTO $(45,74 \pm 2,88 \%)$ pada sapi yang diberi R3, dan dalam pengencer TKT dan TKTO pada sapi yang diberi $\mathrm{R} 1$ dengan motilitas spermatozoa masing-masing $46,87 \pm 3,06 \%$ dan $47,93 \pm 5,88 \%$. Spermatozoa yang dalam pengencer Skim 
ataupun Skim-O pada sapi-sapi yang diberi $\mathrm{R} 2$, R3 dan TKT. Pada sapi yang diberi R2 menunjukkan nilai yang tidak berbeda $(p>0,05)$

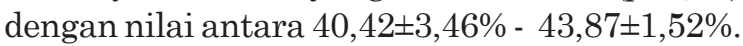

Kombinasi $20 \%$ kuning telur yang ditambahkan ke dalam buffer Tris kelihatannya telah mampu memberi nutrisi dan melindungi spermatozoa saat pembekuan. Motilitas spermatozoa dalam pengencer TKT lebih baik dalam penelitian ini. Seperti halnya laporan Wiratri et al. (2014) dan Herdiawan (2004) yang juga menemukan pengencer TKT lebih baik dari pengencer lainnya. Pengencer TKT tanpa omega3 sama baiknya dengan yang diberi omega-3.

Omega-3 atau Polyunsaturated Fatty Acid (PUFA), mengandung Eicosa Pentaenoic Acid (EPA) dan Docosahexaenoic Acid (DHA). Penambahan omega-3 dalam pengencer semen menurut Towhidi et al. (2013) dan a-tokoferol secara in vitro dapat melindungi spermatozoa domba saat proses kriopreservasi. Penambahan
Omega-3 ke dalam pengencer juga telah dilaporkan oleh Nurcholis et al. (2016). Kandungan PUFA dan DHA Omega-3 diduga dapat meningkatkan daya perlindungan membran plasma sperma domba garut dari cekaman dingin saat proses kriopreservasi. Tidak terbuktinya omega-3 dalam pengencer TKT meningkatkan motilitas spermatozoa semen beku sapi simmental, dalam penelitian diduga akibat dosisnya yang kurang tepat, sehingga perlu dilakukan dengan dosis yang lebih tinggi.

Persyaratan mutu semen beku sapi sesuai Standar Nasional Indonesia (SNI) nomor 4869.1 tahun 2008, semen beku sapi harus menunjukkan motilitas spermaozoa setelah thawing minimal 40\%. Berdasarkan hal tersebut seluruh semen beku yang dihasilkan memenuhi persyaratan mutu tersebut kecuali spermatozoa dalam pengencer Skim dan Skim-O pada ransum 1.

Tabel 7 Motilitas spermatozoa (rerata \pm SEM) semen beku setelah thawing pada sapi simmmental yang diberi ransum berbeda dalam bahan pengencer Skim dan Tris Kuning telur dengan dan tanpa penambahan Omega-3

\begin{tabular}{lcccc}
\hline \multirow{4}{*}{ Pakan } & \multicolumn{4}{c}{ Pengencer } \\
\cline { 2 - 5 } & Skim & Skim-O & TKT & TKT-O \\
\hline R1 & $26,65 \pm 6,84 \mathrm{a}$ & $31,70 \pm 0,86 \mathrm{ab}$ & $46,87 \pm 3,06 \mathrm{c}$ & $47,93 \pm 5,88 \mathrm{c}$ \\
R2 & $40,42 \pm 3,46 \mathrm{bc}$ & $40,28 \pm 5,68 \mathrm{bc}$ & $43,87 \pm 1,52 \mathrm{bc}$ & $49,72 \pm 0,52 \mathrm{c}$ \\
R3 & $43,23 \pm 3,4 \mathrm{bc}$ & $41,46 \pm 5,25 \mathrm{bc}$ & $45,42 \pm 2,81 \mathrm{c}$ & $45,74 \pm 2,88 \mathrm{c}$ \\
\hline
\end{tabular}

Keterangan: R1= Pakan standar; R2= Pakan dengan supplementasi Zn dan Se minimal; R3= Pakan dengan supplementasi Zn dan Se maksimal; TKT = Tris Kuning Telur; $\mathrm{O}=$ Omega-3; Huruf berbeda yang mengikuti angka pada baris dan kolom yang sama menunjukkan perbedaan nyata $(\mathrm{p}<0,05)$

Tabel 8. Skor gerakan individu spermatozoa sapi simmental yang diberi tiga ransum berbeda dalam pengencer Skim dan Tris kuning telur dengan dan tanpa suplementasi omega-3

\begin{tabular}{lcccc}
\hline \multirow{2}{*}{ Ransum } & \multicolumn{4}{c}{ Pengencer } \\
\cline { 2 - 5 } & Skim & Skim-O & TKT & TKT-O \\
\hline R1 & $2,09 \pm 0,21 \mathrm{a}$ & $2,26 \pm 0,10 \mathrm{a}$ & $2,84 \pm 0,14 \mathrm{a}$ & $2,79, \pm 0,17 \mathrm{a}$ \\
R2 & $2,49 \pm 0,19 \mathrm{a}$ & $2,34 \pm 0,26 \mathrm{a}$ & $2,62 \pm 0,05 \mathrm{a}$ & $2,87 \pm 0,07 \mathrm{a}$ \\
R3 & $2,53 \pm 0,30 \mathrm{a}$ & $2,57 \pm 0,07 \mathrm{a}$ & $2,56 \pm 0,07 \mathrm{a}$ & $2,57 \pm 0,10 \mathrm{a}$ \\
\hline
\end{tabular}

Keterangan: R1= Pakan standar; R2= Pakan dengan supplementasi Zn dan Se minimal; R3= Pakan dengan supplementasi Zn dan Se maksimal; TKT = Tris Kuning Telur; O= Omega-3; Huruf berbeda yang mengikuti angka pada baris dan kolom yang sama menunjukkan perbedaan nyata $(\mathrm{p}<0,05)$ 
Selain motilitas, persyaratan mutu yang tercantum dalam SNI semen beku sapi adalah skor individu (kecepatan sel bergerak progresif). Skor individu spermatozoa semen beku disajikan pada Tabel 8. Skor individu spermatozoa semen beku yang dihasilkan dalam penelitian ini adalah 2,09 $\pm 0,21$ sampai $2,87 \pm 0,07$ dan tidak terdapat perbedaan antar perlakuan pakan ataupun pengencer yang digunakan. Seluruh semen beku mempunyai skor gerakan individu lambat sampai sedang. Persyaratan mutu semen beku sapi harus menunjukkan minimal 2 . Artinya semua semen beku memenuhi persyaratan mutu yang ditetapkan baik motilitas spermatozoa ataupun skor gerakan individu.

Viabilitas spermatozoa adalah parameter uji tambahan kualitas semen. Pengujian viabilitas spermatozoa digunakan sebagai indikator integritas struktur membran (Sukmawati et al., 2014). Viabilitas spermatozoa dalam berbagai bahan pengencer disajikan pada Tabel 9 . Viabilitas spermatozoa tertinggi $(p<0,05)$ terdapat pada semen yang diencerkan dengan Skim dengan pakan R3 (70,05 $\pm 7,073 \%)$, sedangkan viabilitas paling rendah terdapat pada sperma dalam pengencer Skim-omega3 yang diberi pakan $\mathrm{R} 1(44,81 \pm 6,12 \%)$. Semen dalam pengencer TKT dan TKTO pada R1, R2 dan R3 tidak berbeda, dengan nilai 52,96 $\pm 5,96$ sampai $60,73 \pm 8,02 \%$.

Rendahnya viabilitas spermatozoa pada perlakuan pakan R1 dalam pengencer Skim, kemungkinan karena komposisi pakan $\mathrm{R} 1$ dan pengencer Skim, kurang tepat untuk sapi simmental. Sebaliknya pada sapi-sapi yang diberi R1, namun dalam pengencer TKT dan TKT-O, terlihat bahwa kuning telur dan omega 3 dapat melindungi membran spermatozoa selama pembekuan dan thawing. Nilai viabilitas spermatozoa pada semen sapi berbeda-beda, bergantung pengencer dan rumpun sapi yang digunakan Arifiantini dan Yusuf (2010) melaporkan viabilitas spermatozoa sapi $\mathrm{FH}$ dalam pengencer Tris kuning telur dan

Tabel 9. Viabilitas spermatozoa sapi simmental yang diberi tiga ransum berbed dalam pengencer Skim dan Tris kuning telur dengan dan tanpa suplementasi omega-3

\begin{tabular}{lcccc}
\hline \multirow{2}{*}{ Ransum } & \multicolumn{4}{c}{ Pengencer semen } \\
\cline { 2 - 5 } & Skim & Skim-O & TKT & TKT-O \\
\hline R1 & $46,29 \pm 4,08 \mathrm{ab}$ & $44,81 \pm 6,12 \mathrm{a}$ & $52,96 \pm 5,96 \mathrm{abc}$ & $53,86 \pm 11,44 \mathrm{abc}$ \\
R2 & $56,67 \pm 3,26 \mathrm{abc}$ & $62,62 \pm 5,7 \mathrm{abc}$ & $54,65 \pm 3,83 \mathrm{abc}$ & $60,73 \pm 8,02 \mathrm{abc}$ \\
R3 & $70.05 \pm 7,073 \mathrm{c}$ & $68.96 \pm 10.28 \mathrm{bc}$ & $58.05 \pm 2.39 \mathrm{abc}$ & $59.11 \pm 7,13 \mathrm{abc}$ \\
\hline
\end{tabular}

Keterangan: R1= Pakan standar; R2= Pakan dengan supplementasi Zn dan Se minimal; R3= Pakan dengan supplementasi Zn dan Se maksimal; TKT = Tris Kuning Telur; O=Omega-3; Huruf berbeda yang mengikuti angka pada baris dan kolom yang sama menunjukkan perbedaan nyata $(\mathrm{p}<0,05)$

Tabel 10. Keutuhan membran plasma spermatozoa sapi simmental yang diberi tiga ransum berbeda dalam pengencer Skim dan Tris kuning telur dengan dan tanpa suplementasi omega-3

\begin{tabular}{lcccc}
\hline & \multicolumn{4}{c}{ Pengencer } \\
\cline { 2 - 5 } Ransum & Skim & Skim-O & TKT & TKT-O \\
\hline R1 & $72,17 \pm 2,50 \mathrm{abc}$ & $72,39 \pm 0,55 \mathrm{abc}$ & $76,50 \pm 3,46 \mathrm{bc}$ & $74,22 \pm 4,88 \mathrm{abc}$ \\
R2 & $68,14 \pm 1,71 \mathrm{ab}$ & $71,26 \pm 4,35 \mathrm{abc}$ & $72,36 \pm 4,27 \mathrm{abc}$ & $64,15 \pm 3,21 \mathrm{a}$ \\
R3 & $72,13 \pm 2,15 \mathrm{abc}$ & $72,41 \pm 0,49 \mathrm{abc}$ & $81,85 \pm 6,20 \mathrm{c}$ & $74,13 \pm 4,54 \mathrm{abc}$ \\
\hline
\end{tabular}

Keterangan: R1= Pakan standar; R2= Pakan dengan supplementasi Zn dan Se minimal; R3= Pakan dengan supplementasi Zn dan Se maksimal; TKT = Tris Kuning Telur; O= Omega-3; Huruf berbeda yang mengikuti angka pada baris dan kolom yang sama menunjukkan perbedaan nyata $(\mathrm{p}<0,05)$ 
andromed hampir sama yaitu $65,10 \%$ dan $65,06 \%$, namun dalam Tris soya lebih rendah hanya $58,30 \%$.

Membran plasma merupakan bagian yang melindungi organel-organel sel. Keutuhan membran plasma (MPU) sangat penting untuk diuji. Nilai MPU spermatozoa semen beku sapi simmental disajikan pada Tabel 10. Nilai MPU tertinggi $(p<0,05)$ ditunjukkan oleh spermatozoa dalam pengencer TKT $(81,85 \pm 6,20 \%)$ pada sapi yang diberi pakan R3. Nilai terendah terdapat pada spermatozoa dalam pengencer TKTO, pada sapi yang diberi pakan R2. Tidak terdapat perbedaan nilai MPU pada pengencer lainnya.

Nilai MPU pada penelitian berbeda dengan yang dilaporkan oleh Priyanto et al. (2015) yaitu $67,01 \%$, hal ini disebabkan karena peneliti tersebut menggunakan rumpun sapi yang berbeda-beda yaitu sapi brahman, ongole, simmental dan limosin. Sukmawati et al. (2014) melaporkan nilai MPU pada sapi simmental dalam pengencer skim hanya $61,72 \%$.

\section{Penurunan Motilitas Spermatozoa Sapi Simmental}

Pada saat proses pembekuan dan thawing spermatozoa mengalami berbagai perubahan suhu dan tekanan osmotik sehingga menurunkan kualitas semen, di antaranya adalah penurunan motilitas, skor gerakan individu, viabilitas, membran plasma utuh sperma. Penuruan kualitas tidak bisa dihindari, namun diupayakan dicari komponenkomponen yang bisa ditambahkan dalam bahan pengencer untuk mengurangi kerusakan sel. Penurunan motilitas spermatozoa selama proses pembekuan disajikan pada Tabel 11.

Penurunan motilitas spermatozoa semen segar setelah ekuilibrasi masih rendah, hanya sekitar 3,33-18,33\%. Tanpa memperhitungan jenis pengencer yang digunakan, spermatozoa dari sapi-sapi yang diberi pakan R1 menunjukkan penurunan yang paling tinggi yaitu $14,16 \%$ dibandingkan R2 dan R3 hanya 4,16 dan 5,83 . Sebaliknya tanpa mempertimbangkan ransum yang diberikan pengencer Skim, Skim-O, TKT dan TKTO menunjukkan nilai yang hampir sama yaitu 6,66 sampai $11,11 \%$.

Ekuilibrasi dilakukan pada suhu $5^{\circ} \mathrm{C}$ selama 4 jam. Tujuan ekuilibrasi adalah penyesuaian spermatozoa sebelum dibekukan agar tidak mengalami shock yang berlebihan. Saat ekuilibrasi juga terjadi penyesuain bahan pengencer dan spermatozoa. Perubahan suhu dari suhu ruang $\left(20-22^{\circ} \mathrm{C}\right)$ saat pengenceran dan

Tabel 11. Penurunan motilitas spermatozoa (\%) sapi simmental selama proses pembekuan setelah pemberian pakan dan pengencer berbeda

\begin{tabular}{lccccc}
\hline $\begin{array}{l}\text { Tahapan } \\
\text { pembekuan/ } \\
\text { Ransum }\end{array}$ & Skim & Skim-O & TKT & TKT-O & Rerata \\
\cline { 2 - 5 } & \multicolumn{3}{c}{ Pengencer } \\
\hline $\begin{array}{l}\text { Semen segar ke setelah ekuilibrasi } \\
\text { R1 }\end{array}$ & 11,66 & 18,33 & 13,33 & 13,33 & 14,16 \\
R2 & 3,33 & 4,99 & 4,99 & 3,33 & $\mathbf{4 , 1 6}$ \\
R3 & 6,67 & 10 & 3,33 & 3,33 & $\mathbf{5 , 8 3}$ \\
$\quad$ Rataan & 7,22 & 11,11 & 7,216667 & 6,66 & \\
Setelah ekuilibrasi ke setelah thawing & & & & \\
R1 & 35,02 & 23,3 & 13,13 & 12,07 & 20,88 \\
R2 & 22,91 & 21,39 & 17,8 & 10,28 & 18,09 \\
R3 & 20,1 & 18,54 & 21,25 & 20,93 & 20,20 \\
Rataan & 26,01 & 21,08 & 17,39 & 14,43 & \\
Penurunan total & & & & & \\
R1 & 46,68 & 41,63 & 26,46 & 25,4 & 35,04 \\
R2 & 26,24 & 26,38 & 22,79 & 16,94 & $\mathbf{2 3 , 0 9}$ \\
R3 & 26,77 & 28,54 & 24,58 & 24,26 & $\mathbf{2 6 , 0 4}$ \\
Rataan & 33,23 & 32,18 & 24,61 & 22,20 & \\
\hline
\end{tabular}

Keterangan: R1= Pakan standar; R2= Pakan dengan supplementasi Zn dan Se minimal; R3= Pakan dengan supplementasi Zn dan Se maksimal; TKT = Tris Kuning Telur; O=Omega-3; Huruf berbeda yang mengikuti angka pada baris dan kolom yang sama menunjukkan perbedaan nyata $(\mathrm{p}<0.05)$ 
pengemasan dilakukan ke suhu ekuilibrasi, otomatis akan menyebabkan penurunan motilitas, namun penurunan umumnya hanya sekitar 8,7\% sampai 10-15\% (Baharun et al., 2007; Komariah et al., 2013).

Penurunan motilitas setelah ekuilibibrasi dan setelah thawing cukup tinggi berkisar antara 18,09 sampai $20,88 \%$ pada $R 1$, R2 dan R2. Tanpa melihat jenis ransum, bahan pengencer TKTO motilitas spermatozoa turun sebanyak 14,43\% sedangkan TKT, Skim-O dan Skim turun motilitasnya berturut-turut adalah 17,39; 21,80 dan 26,01\%. Penurunan tersebut hampir sama dengan laporan Baharun et al. (2017) yaitu 19,1 sampai $24,46 \%$ pada sapi pasundan dengan pengencer TKT, Tris soya lesitin dan pengencer komersial. Penurunan antara 19 sampai $21 \%$ juga dilaporkan oleh Komariah et al. (2013) pada sapi limosin, simmental dan FH. Tingginya penurunan motilitas spermatozoa ini akibat suhu yang ekstrim saat pembekuan yang dapat menyebabkan pembentukan kristal es dan efek larutan yang mengandung krioprotektan.

Total penurunan motilitas spermatozoa semen segar setelah thawing pada sapi-sapi yang diberi R1, R2 dan R3 masing-masing adalah 35,04; 23,09; dan 26,04\%. Penurunan motilitas spermatozoa pada pengencer Skim, Skim-O, TKT dan TKTO masing-masing adalah 33,$23 ; 32,18 ; 24,61$ dan 22,20\%. Total penurunan motilitas spermatozoa semen segar setelah thawing memang tinggi, hal ini dapat dipahami mengingat spermatozoa mengalami berbagai perubahan suhu ekstrim. Mulai dari suhu penyimpanan dalam epididimis jantan sekitar $32^{\circ} \mathrm{C}$, dikoleksi menggunakan vagina buatan dan disimpan sementara dalam penangas air/ water bath $\left(32^{\circ} \mathrm{C}\right)$ selama evaluasi semen, diencerkan dalam ruangan laboratorium (20$22^{\circ} \mathrm{C}$ ), diekuilibrasi $5^{\circ} \mathrm{C}$ selama 4 jam dan dibekukan dalam uap nitrogen pada suhu sekitar $-130^{\circ} \mathrm{C}$, dilanjutkan dengan penyimpanan pada suhu $-196^{\circ} \mathrm{C}$ selama 24 jam. Pengujian keberhasilan pembekuan dilakukan dengan cara thawing semen beku menggunakan suhu $37^{\circ} \mathrm{C}$ selama 30 detik.

Setiap perubahan suhu akan menyebabkan kerusakan sel terutama pada suhu kritis dari $15^{\circ} \mathrm{C}$ ke $-60^{\circ} \mathrm{C}$. Suhu kritis akan dialami dua kali oleh spermatozoa saat pembekuan dan saat thawing. Perubahan-perubahan tersebut berpotensi merusak membran plasma dan akrosom spermatozoa yang pada akhirnya akan berpengaruh pada penurunan motilitas spermatozoa (Bag et al., 2004). Penurunan motilitas spermatozoa dalam penelitian ini serupa dengan laporan Komariah et al. (2013) dan Baharun et al., (2017) yaitu penuruan total motilitas spermatozoa selama pembekuan adalah sekitar 23,77 sampai 33,96\%, bahkan pada pengencer Tris dengan sari kedelai kerusakan mencapai 43,07\% (Baharun et al., 2017).

Pemberian omega-3 dalam pengencer Skim dan TKT hanya terbukti meningkatkan motilitas sperma pada semen beku sapi-sapi yang diberi $\mathrm{R} 1$, pada ransum lain kelihatan belum berfungsi seperti yang diharapkan. Pengencer TKT dan TKTO menunjukkan nilai yang sama pada semua peubah yang diuji, keduanya lebih baik daripada Skim ataupun Skim-O pada semua jenis ransum. Omega-3 adalah asam lemak tak jenuh yang penting untuk proses fisiologi termasuk reproduksi (Mattos et al., 2000). Adams et al. (2008), menyatakan bahwa suplementasi omega-3 memberikan efek positif dalam meningkatkan motilitas spermatozoa kuda. Pengencer Tris dengan kuning telur yang mengandung omega3 dapat melindungi membran plasma spermatozoa domba lokal (Nalley dan Arifiantini, 2011).

Omega-3 memberikan efek positif terhadap kualitas spermatozoa domba (Samadian et al., 2010; Esmaeili et al., 2014) dan semen sapi (Moallem et al., 2015). Omega-3 dapat juga ditambahkan dalam pakan ternak. Ternak babi yang diberi omega-3 dapat meningkatkan konsentrasi fosfolipid dalam semen (Rooke et al., 2001), sehingga terjadi peningkatan kualitas semen.

Hasil penelitian ini belum dapat membuktikan manfaat omega-3 dalam pengencer semen kecuali pada sapi yang diberi ransum $\mathrm{R} 1$. Belum terbuktinya omega 3 dalam memperbaiki kualitas semen beku dalam pengencer Tris kemungkinan akibat kurangnya dosis yang diberikan, dosis omega-3 yang diberikan adalah 0,5\% sehingga perlu dicari dosis omega-3 yang paling tepat untuk semen sapi. Kaka et al. (2015) melaporkan bahwa dosis omega-3 sebanyak 3, 5, 10, dan $15 \mathrm{ng} / \mathrm{mL}$ dalam pengencer semen sapi dapat meningkatkan kualitas spermatozoa setelah pendinginan dan pembekuan. Towhidi et al. (2013) juga melaporkan dosis omega-3 sebanyak 0,1, 1 and $10 \mathrm{ng} / \mathrm{mL}$ nyata meningkatkan karakteristik semen beku domba.

Hasil penelitian ini dapat memberikan 
pilihan pada BIB, yaitu BIB dapat memilih untuk mendapatkan kualitas semen beku sapi simmental yang baik. Jika menggunakan ransum standar maka harus menggunakan pengencer Tris kuning telur, atau menggunakan ransum yang disuplementasi mineral dapat menggunakan pengencer Skim atau TKT

\section{SIMPULAN}

Motilitas spermatozoa sapi yang diberi Ransum 1 dalam pengencer Tris kuning telur dan Ransum 3 dalam pengencer Tris kuning telur dan Omega-3 paling tinggi. Viabilitas spermatozoa tertinggi pada sapi yang diberi ransum standar dalam pengencer Skim-omega3 dan keutuhan membran plasma spermatozoa tertinggi pada sapi yang diberi pakan $\mathrm{R} 2$ dalam pengencer Tris kuning telur

\section{SARAN}

Balai inseminasi buatan dapat menggunakan pengencer Tris kuning telur untuk semen beku sapi simmental.

\section{UCAPAN TERIMA KASIH}

Terima kasih kami ucapkan kepada Kepala Balai Inseminasi Buatan Lembang, Bandung yang telah memberikan izin dan fasilitas penelitian, sehingga bisa dilaksanakan dengan baik

\section{DAFTAR PUSTAKA}

Arifiantini I. 2012. Teknik koleksi dan evaluasi semen pada hewan. Bogor. IPB Press.

Arifiantini RI, Yusuf TL . 2010. Developing of Tris Soy Milk Diluent For FH Bull Frozen Semen. 2010. Hayati Biosci 17(2): 91-94

Arlindo SN, Zanetti M A, Del Claro GR, de Melo M P, Vilela FG, Correa LB . 2014. Effects of Copper and Selenium Supplementation on Performance and Lipid Metabolism in Confined Brangus Bulls. Asian Australas. J Anim Sci 27(4): 488-494.

Ax RL, Dally MR , Didion BA, Lenz RW , Love
CC, Varner DD, Hafez B, Bellin ME . 2000. Semen Evaluation. In : Hafez ESE, B. Hafez Editor. Reproduction in Farm Animal. 7th ed . USA: Lippincot Wiliams and Wilkins

Bag S, Joshi A, Naqvi SMK, Mittal JP. 2004. Effect of post-thaw incubation on sperm kinematics and acrosomal integrity of ram spermatozoa cryopreserved in medium-sized French straws. Theriogenology 62: 415-424.

Balai Inseminasi Buatan Lembang. 2011. Prosedur Penampungan Semen. Bandung

Boitani C, Puglisi R. 2008. Selenium, a key element in spermatogenesis and male fertility. Adv Exp Med Biol 636: 65-73

Cheah Y, Yang W. 2011. Functions of essential nutrition for high quality spermatogenesis. Adv in Biosci and Biotech 2: 182-197

Esmaeili V, Shahverdi AH, Alizadeh AR, Alipour H, Chehrazi M. 2014. Saturated, omega-6 and omega-3 dietary fatty acid effects on the char-acteristics of fresh, frozen-thawed semen and blood parameters in rams. Andrologia 46(1): 42-49.

Fonseca JF, Torres CAA, Maffili VV, Borges AM, Santos ADF, Rodrigues MT, Oliveira RFM. 2005. The hypoosmotic swelling test in fresh goat spermatozoa. Anim Reprod 2(2): 139144.

Ganabadi SJr, Halimatun Y, Choong KLA, Nor JA, Hilmi MA. 2010. Effect of selenium supplementation on spermatogenic cells of goats. Mal J Nutr 16(1): 187-193.

Herdiawan. 2004. Pengaruh laju penurunan suhu dan jenis pengencer terhadap kualitas semen beku domba priangan. Jurnal Ilmu Ternak dan Veteriner 9(2): 98107.

Kaka A, Wahid H, Leghari RA, Memon MI, Kaka U, Mirani AH, Naeem M, Kalwar Q. 2016. Effect of invitro supplementation of polyunsaturated fatty acids on frozenthawed bull sperm characteristics using Bioxcell ${ }^{\circledR}$ extender. Pure Appl. Biol 5(3): 399-405.

Komariah, Arifiantini I, Nugraha FW. 2013. Sapi Simmental, Limousin, dan Friesian Holstein Terhadap Proses Pembekuan. Buletin Peternernalakan 37(3): 143-147 
Kumar N, Verma RP, Singh LP, Varshney VP, Dass RS. 2006. Effect of different levels and sources of zinc supplementation on quantitative and qualitative semen attributes and serum testosterone level in crossbred cattle (Bos indicus $\times$ Bos taurus) bulls. Reprod Nutr Dev 46: 663-675

Moallem U, Neta N, Zeron Y, Zachut M, Roth Z. 2015. Dietary á-linolenic acid from flaxseed oil or eicosapentaenoic and docosahexaenoic acids from fish oil differentially alter fatty acid composition and characteristics of fresh and frozen-thawed bull semen. Theriogenology 83(7): 11101120 .

Nalley WMM, Arifiantini RI. 2011. The Viability of local Ram semen in Tris buffer with three different egg yolks. Anim Prod 13(1): 39-44

National Research Council. 2001. Nutrient Requirements of Beef Cattle. Washington, DC. Acad Sci NRC.

Nebel RL. 2007. Techniques for artificial insemination of cattle with frozen thawed semen. in: Current Therapy In Large Animal Theriogenol. $2^{\text {nd }}$ Ed. Missouri. Saunders Elselvier.

Nurcholis, Arifiantini RI, Yamin M. 2016. Kriopreservasi semen domba garut menggunakan tris kuning telur yang disuplementasi omega-3 minyak ikan salmon. $J$ Veteriner 17(2): 309-315.

Nursyam. 2007. Perkembangan Iptek Bidang Reproduksi Ternak Untuk Meningkatkan Produktivitas Ternak. http//:www.unlam. ac.id./journal/pdf_file. Diakses pada tanggal 22 November 2012
Priyanto L, Arifiantini RI, Yusuf TL.2015. Deteksi Kerusakan DNA Spermatozoa Semen Segar dan Semen Beku Sapi Menggunakan Pewarnaan Toluidine Blue. $J$ Veteriner 16(1): 48-55

Rooke JA, Shao CC, Speake BK. 2001. Effects of feeding tuna oil on the lipid composition of pig spermatozoa and in vitro characteristics of semen. Reproduction 121(1): 315-322.

Rowe MP, Powell JG, Kegley EB, Lester TD, Williams CL, Page RJ, Rorie RW. 2013. Influence of organic versus inorganic trace mineral supplementation on bull semen quality. AAES Research Series 597. pp 1113. http://arkansasagnews.uark.edu/5971.pdf

Samadian S, Towhidi A, Rezayazdi K, Bahreini M. 2010. Effects of dietary n " 3 fatty acids on characteristics and lipid composition of ovine sperm. Animal 4(1): 2017-2022.

Sukmawati E, Arifiantini RI, Purwantara B. 2014. Daya Tahan Spermatozoa terhadap Proses Pembekuan pada Berbagai Jenis Sapi Pejantan Unggul. Jurnal Ilmu Ternak dan Veteriner 19(3): 168-175.

Towhidi A, Zeinoaldini S, Ardebili R, Davachi ND, Nasiri AH. 2013. Combined n-3Fatty Acids and á-Tocopherol Supplementation Improved the Ovine Sperm Cryosurvival. Iranian J of Biotech 11(4): 238-243. 